\title{
Prediksi Financial Distress Berdasarkan Variabel-Variabel Keuangan Pada Industri Tekstil
}

\author{
REFNI SUKMADEWI \\ Dosen Tetap Akademi Sekretari dan Manajemen Persada Bunda \\ J1. Diponegoro No. 42 Pekanbaru \\ E-mail: Soekma_dhewi@yahoo.co.id
}

\begin{abstract}
This research aims at providing empirical evidance on factors that affect firms financial distress. This research examines the role of financial ratios in predicting the occurance of financial distress at firm in textiles industry listed at Bursa Efek Jakarta. Discriminant analysis used to test the ability of financial ratio to predict financial distress and construct financial distress prediction model by using stepwise procedure. Variabel indicator are financial ratios. The result shows that there are four ratios different and significantly effect financial distress prediction model. The ratios are Rasio Current Asset/Current Liability, Working Capital/Total Asset, Net Income/Total Asset, Liability/Total Aset. The classificaton results based on the cut-off-Z Score values able to predict firms financial distress in textiles industry at the accuracy rate of $100 \%$. The accuracy rate of model shows that discriminant model is accurate in measuring financial distress at firms in textile industry.
\end{abstract}

Keywords: Financial distress, Prediction Models, Financial Ratios

Keberadaan industri dalam suatu negara dapat dipengaruhi oleh berbagai faktor, salah satunya adalah lingkungan. Lingkungan tersebut dapat dibagi menjadi dua kategori, yaitu lingkungan internal dan lingkungan eksternal. Lingkungan internal merupakan lingkungan dari dalam perusahaan yang dapat diubah, dan diatur oleh perusahaan sesuai dengan kebutuhannya. Lingkungan eksternal merupakan lingkungan yang berada di luar perusahaan yang tidak dapat dikontrol oleh perusahaan. Salah satu faktor dalam lingkungan eksternal yang paling berpengaruh dalam suatu perusahaan adalah faktor ekonomi.

Kondisi ekonomi global terus berubah dari waktu ke waktu, begitupun dengan Indonesia. Kondisi ekonomi di Indonesia terus berubah dari satu periode ke periode lainnya. Setiap tahun, Indonesia mengalami kejadian ekonomi, yang berpengaruh pada situasi ekonomi global maupun regional.

Sektor industri merupakan motor penggerak bagi pertumbuhan perekonomian menuju keadaan yang lebih baik karena sektor industri dianggap efisien dalam menggunakan sumber daya ekonomi. Namun dalam beberapa tahun, kinerja sektor industri tanah air turun. Hal ini disebabkan kenaikan harga bahan bakar minyak yang menyebabkan menurunnya daya beli masyarakat.

Industri manufaktur merupakan sektor terbesar didalam produk domestik bruto (PDB) Indonesia. Sumbangan besar industri manufaktur terhadap perekonomian adalah dalam hal penyerapan tenaga kerja dan penghasilan devisa negara dari ekspor. Dewasa ini industri manufaktur di Indonesia sudah berada diujung kesulitan yang ditandai dengan menurunnya pertumbuhan industri manufaktur yang cukup tajam.

Industri tekstil dan garmen di Indonesia menjadi salah satu tulang punggung industri manufaktur dan merupakan industri prioritas nasional yang masih prospektif untuk dikembangkan. Industri tekstil dan garmen memberikan kontribusi cukup besar terhadap pertumbuhan ekonomi, selain menciptakan lapangan kerja cukup besar, industri ini mendorong peningkatan investasi dalam dan luar 
negeri. Industri tekstil dan garmen merupakan industri padat karya, yang sedikitnya menyerap 1,8 juta pekerja. Dari sisi tenaga kerja, pengembangan atau penambahan kapasitas industri dapat dengan mudah terakomodasi oleh melimpahnya tenaga kerja dan upah yang kompetitif, khususnya dibandingkan dengan kondisi di industri negara maju. Industri tekstil adalah industri yang berorientasi ekspor.

Industri tekstil dan garmen di Indonesia saat ini sedang menghadapi tantangan sekaligus menghadapi tekanan ditengah globalisasi dunia untuk perdagangan bebas. Pemberlakuan perjanjian perdagangan bebas antara Indonesia dengan beberapa negara memberikan tekanan cukup berat bagi industri tekstil nasional khususnya di pasar.

Prediksi terhadap perusahaan yang mengalami kesulitan keuangan merupakan suatu studi yang menarik. Analisis financial distress sangat membantu dalam mengambil keputusan untuk melihat kemampuan perusahaan mengelola kasnya. Perusahaan secara tepat waktu diharapkan dapat memenuhi kewajiban membayar bunga, cicilan hutang, dan penyediaan modal kerja

Penelitian akademis bisa menyediakan model untuk mencegah financial distress yang sangat diperlukan di Indonesia. Keberadaan model diharapkan membantu perusahaan, investor, kreditor dan pihak lain untuk mengawasi kinerja keuangan perusahaan. Ada cara yang bisa menggambarkan kondisi keuangan perusahaan pada pasar di Indonesia dengan membuat model prediksi untuk memprediksi kemungkinan finacial distress perusahaan di Indonesia sebagai instrumen peringatan dini yang dirumuskan sebagai berikut: meskipun indikator yang memberikan kontribusi dominan terhadap kemungkinan financial distress perusahaan belum jelas, tetapi rasio keuangan bisa memberikan gambaran kondisi keuangan perusahaan. Karena itu dibangun model berdasarkan rasio keuangan yang diharapkan dengan model tersebut adalah sebagai peringatan dini untuk memprediksi financial distress perusahaan.

Altman memformulasikan model prediksi kesulitan keuangan dengan menggunakan lima rasio keuangan yang dikenal dengan Altman $\mathrm{Z}$ Score. Menggunakan analisis diskriminan linier dengan akurasi $95 \%$ kasus finacial distress pada satu tahun sebelum kesulitan keuangan terjadi. Analisis diskriminan yang dipakai dalam formulasi $\mathrm{Z}$ Score umumnya dipakai untuk mengklasifikasikan sekumpulan observasi kedalam beberapa kelompok, biasanya variabel dependen yang akan diformulasikan bersifat kualitatif, seperti distress atau tidak distress. Secara sederhana, anallisis diskriminan akan menghasilkan kombinasi linier dari karakteristik-karakteristik dalam kelompok yang membedakan secara signifikan kelompok tersebut yaitu kelompok distress dan yang tidak distress. Z-Score yang pertama kali dikembangkan untuk menentukan kecenderungan finacial distress dapat juga digunakan sebagai ukuran dari keseluruhan kinerja keuangan perusahaan. Hal yang menarik dari Z-Score adalah keandalannya sebagai alat analisis tanpa memperhatikan bagaimanan ukuran perusahaan.

\section{METODE}

Data berupa data kuantitatif dari laporan keuangan dari semua industri tekstil yang dijadikan objek penelitian yaitu sebanyak 14 perusahaan. Sumber data berasal dari laporan keuangan yang sudah di audit dari PT Bursa Efek Indonesia. Penelitian bersifat deskriptif dan eksploratif yang bertujuan untuk membuat gambaran secara sistematis, faktual dan akurat mengenai fakta yang ditemukan pada perusahaan-perusahaan menggunakan data sekunder dari laporan tahunan dari Burse Efek Indonesia. Analisis deskriptif

$$
\text { p.ISSN: 2407-800X e.ISSN: 2541-4356 }
$$


dilakukan untuk memperoleh kejelasan mengenai variabel yang akan diteliti. Penelitian eksploratif berusaha untuk mencari ide-ide atau hubungan-hubungan yang baru dan tidak menggunakan hipotesis. Data berupa 14 rasio keuangan di analisis menggunakan analisis diskriminan menggunakan bantuan program SPSS.

\section{HASIL}

Identifikasi suatu objek bertujuan untuk mengetahui apakah objek-objek penelitian dapat digunakan untuk menguji perbedaan suatu kelompok terhadap kelompok lain. Objek yang dimaksud adalah rasio keuangan. Identifikasi rasio keuangan dilakukan dengan cara menguji kesamaan rata-rata kelompok yang dapat digunakan dengan 2 cara, yaitu:

Besarnya angka Wilks' Lambda adalah antara angka 0 sampai angka 1. Jika angka mendekati 0 , maka data cenderung berbeda sebaliknya jika angka mendekati 1 maka data cenderung sama.

Ada empat variabel yang mempunyai angka signifikan yang mendekati 0 yaitu variabel X3 (Working Capital/Total Asset), variabel X9 (Net Income/Total Asset), X11 (Liability / Total Asset), X12 (Equity/Total Asset). Dengan demikian empat variabel tersebut merupakan faktor pembeda dalam memprediksi financial distress antara dua kelompok, yaitu kelompok distress dan yang tidak distress.

Dalam uji ini akan dilihat variabel independen mana saja yag berbeda secara signifikan diantara kelompok yang diprediksi distress dan yang tidak distress menggunakan kriteria $\mathrm{F}$ test. Kriteria uji menggunakan ketentuan berikut: Jika signifikan $>0,05$, maka tidak akan ada perbedaan dalam kelompok; Jika signifikan <0,05, maka ada perbedaan dalam kelompok.

Ada empat variabel yang mempunyai angka signifikan lebih kecil dari 0,05 yaitu variabel X3 (Working Capital/Total Asset), variabel X9 (Net Income/Total Asset), X11 (Liability / Total Asset), X12 (Equity/Total Asset). Dengan demikian empat variabel tersebut merupakan faktor pembeda dalam memprediksi financial distress antara dua kelompok, yaitu kelompok distress dan yang tidak distress.

Jika dilihat pengujian menggunakan kriteria Wilks' Lambda dan kiteria angka F terdapat kesamaan variabel-variabel independen yang dianggap signifikan. Setelah dilakukan uji rata-rata kelompok diatas, selanjutnya dari empat variabel yang dianggap signifikan ini, akan dilanjutkan dengan menguji signifikan perbedaan antara kedua kelompok dan mencari faktor-faktor pembeda yang mempengaruhi terbentuknya klasifikasi dua kelompok, yaitu kelompok yang distress (0) dan kelompok yang tidak distress (1) dengan menggunakan metode stepwise.

Model diskriminan dibentuk dengan menggunakan metode stepwise dimana Mahalanobis distance menjadi kriteria discriminating power dari masing-masing variabe independen. Prosedur stepwise dilakukan untuk menentukan variabelvariabel independen mana yang efisien dalam membedakan distress atau tidak distress nya perusahaan. Prosedur stepwise dimulai dengan memilih rasio keuangan yang dikeluarkan dari model dan memilih rasio yang memaksimumkan jarak Mahalanobis antar kelompok.

Dari empat variabel independen yang dianggap signifikan menggunakan kriteria angka Wilks' Lambda dan angka F tadi, ada dua variabel independen yang dianggap memiliki discriminating power paling tinggi, artinya yang palingg membedakan diantara kelompok.

Dalam memilih variabel independen yang masuk dalam model diskriminan, sesuai aturan dalam metode stepwise ini maka hanya variabel yang mempunyai nilai Mahalanobis distance tinggi yang dimasukkan, lalu periksa apakah nilai signifikansi nya lebih kecil dari 0,05. Jika nilai signifikansi nya lebih kecil dari 0,05 maka variabel tersebut dimasukkan dalam model diskriminan. Tahapan dalam pemasukan variabel independen dalam model diskriminan adalah sebagai berikut: 
1. Memasukkan variabel Working Capital / Total Asset (X3) ke dalam model dengan nilai Mahalanobis distance 7,145 dengan signifikansi 0,004. Pada tahap pertama ini, variabel Working Capital / Total Asset (X3) terpilih.

2. Memasukkan variabel Liability/Asset (X11) ke dalam model dengan nilai Mahalanobis distance 18,966 dengan signifikansi 0,001. Pada tahap kedua ini, Liability/Asset (X11) terpilih.

3. Memasukkan variabel Net Income/Total Asset (X9) ke dalam model dengan nilai Mahalanobis distance 61,083 dengan signifikansi 2.974E-5. Pada tahap kedua ini, Net Income/Total Asset (X9) terpilih.

4. Memasukkan variabel Current Asset/Current Liability (X2) ke dalam model dengan nilai Mahalanobis distance 134,111 dengan signifikansi 7.117E-6. Pada tahap kedua ini, Current Asset/Current Liability (X2) terpilih.

Empat variabel independen yang dimasukkan kedalam prosedur stepwise tadi dianggap paling signifikan. Dengan demikian dapat dikatakan bahwa variabel Working Capital / Total Asset (X3), variabel Liability/Asset (X11), variabel Net Income/Total Asset (X9) dan variabel Current Asset/Current Liability (X2) membedakan kondisi distress atau tidak distress nya perusahaan tekstil.

Wilks' Lambda pada prinsipnya adalah jumlah varian diskriminan yang tidak bisa dijelaskan oleh perbedaan diantara kelompok-kelompok yang diteliti. Jika dilihat angka Wilks' Lambda pada tabel 4, maka terjadi proses tahapan empat kali sesuai dengan jumlah variabel bebas yang memenuhi persyaratan. Pada tahap pertama 49,5\% varian tidak dapat dijelaskan oleh adanya perbedaan antar kelompok, Pada tahap kedua $27 \%$ varian tidak dapat dijelaskan oleh adanya perbedaan antar kelompok , Pada tahap ketiga 10,3\% varian tidak dapat dijelaskan oleh adanya perbedaan antar kelompok pada tahap keempat varian paling kecil yaitu sebesar $5 \%$.

Penurunan angka Wilks' Lambda adalah baik untuk model diskriminan, karena varian yang tidak bisa dijelaskan semakin kecil. Angka signifikan untuk empat variabel adalah lebih kecil dari 0,05. Karena keempat variabel tersebut mempunyai nilai signifikan lebih kecil dari 0,05 maka variabel tersebut mempunyai perbedaan yang signifikan.

Aspek multivariate model dilaporkan dalam tabel 5 Eigenvalues. Canonical correlation menunjukkan hubungan antara nilai diksriminan dengan kelompok. Nilai Canonical correlation yang baik adalah jika memiliki nilai $>0,50$ (50\%). Nilai Canonical correlation sebsar $0,975 \quad(97,5 \%)$ menunjukkan hubungan yang tinggi karena memiliki nilai $>0,50$ $(50 \%)$.

Adanya korelasi antara variabelvariabel independen dengan fungsi diskriminan yang tebentuk. Pada tabel 6 dapat dilihat bahwa variabel X3 (Working Capital / Total Asset) paling erat hubungannya dengan fungsi diskriminan, diikuti oleh variabel X9 (Net Income/Total Asset X11 (Liability/Total Aset) dan X2 Current Asset/Current Liability.

Dari tabel structure matrix tadi dapat dilihat bahwa variabel yang diikutkan dalam proses analisis diskriminan adalah (yang tidak bertandakan huruf a) yaitu variabel X3 (Working Capital / Total Asset) paling erat hubungannya dengan fungsi diskriminan, diikuti oleh variabel X9 (Net Income/Total Asset X11 (Liability/Total Aset) dan X2 Current Asset/Current Liability.

Dari analisis menggunakan model diskriminan diperoleh model sebagai berikut:

$\mathrm{Z}=-2,174+-0,001 \mathrm{X} 2+0,002 \mathrm{X} 3+-0,024$

X9 + 0,007 X11

Dimana

X2 = Current Asset/Current Liability.

$\mathrm{X} 3=$ Working Capital/Total Asset

$\mathrm{X} 9=$ Net Income/Total Asset

$\mathrm{X} 11=$ Liability/Total Aset

Dari fungsi diskriminan yang

p.ISSN: $2407-800 \mathrm{X} \quad$ e.ISSN: $2541-4356$ 
diperoleh, dapat dilihat pada tabel 7 bahwa nilai rata-rata variabel yang paling dominan untuk memprediksi perbedaan kelompok perusahaan yang diprediksi distress dan tidak distress adalah variabel X11 (Liability/Total Asset.), karena memiliki koefisien tertinggi sebesar 0,007. Sedangkan rata-rata variabel yang paling lemah memprediksi kebangkrutan adalah variabel X2 (Liability/Total Asset), karena memiliki koefisien terendah sebesar -0,001.

Untuk masing-masing kelompok terdapat nilai rata-rata untuk nilai $\mathrm{z}$ Score diskriminan yang disebut centroid. Pada tabel 8 terdapat dua kelompok diskriminan yaitu kelompok yang diprediksi distress dan kelompok yang diprediksi tidak distress.

Keakuratan prediktif fungsi diskriminan dicapai dengan classification result. Sebelum mengembangkan classification result, terlebih dahulu menentukan cutting score. Rumus untuk menentukan nilai cutting score adalah sebagai berikut:

$$
\mathrm{Zcu}=\frac{\mathrm{NA} \cdot \mathrm{ZB}+\mathrm{NB} \cdot \mathrm{ZA}}{\mathrm{NA}+\mathrm{NB}}
$$

Dimana:

$$
\begin{aligned}
& \text { Zcu }=\text { Nilai kritis } \\
& \text { NA }=\text { Jumlah grup A } \\
& \text { NB }=\text { Jumlah grup B } \\
& \text { ZA }=\text { Centroid Grup A } \\
& \text { ZB }=\text { Centroid Grup B }
\end{aligned}
$$

Maka perhitungan nilai kritis adalah sebagai berikut:

$$
\begin{aligned}
& =\frac{[(2) \times(-1,654)]+[(12) \times(9,926)]}{2+12} \\
& =8,27
\end{aligned}
$$

Karena critical cutting score sebesar 8,27 maka prosedur untuk mengklasifikasikan perusahaan adalah: Z> 8,27; perusahaan yang dikategorikan bangkrut $\mathrm{Z}<\mathrm{8,27}$; perusahaan yang dikategorikan tidak bangkrut

Selanjutnya dilakukan prosedur casewise statistic untuk mengevaluasi tingkat keberhasilan model diskriminan yang dihasilkan dalam mengidentifikasi financial distress pada perusahaan industri tekstil.
Hasil prosedur casewise statistic berupa nilai Z Score dan hasil yang diperoleh berdasarkan nilai $\mathrm{Z}$ Score menggunakan model diskriminan.

Prediksi financial distress ditentukan dengan melihat nilai equity perusahaan. Bila nilai equity positif maka dikategorikan perusahaan yang tidak bangkrut, sedangkan bila equity negatif maka dikategorikan perusahaan yang bangkrut. Berdasarkan nilai equity tersebut terdapat dua perusahaan yang bangkrut yaitu PT Asia Pacific Fibers Tbk, dan PT Argo Pantes Tbk. Sedangkan 12 perusahaan lainnya tidak bangkrut.

Dari prosedur casewise statistic dapat dilihat mana saja perusahaan yang memiliki nilai Z> 8,27 yaitu perusahaan yang dikategorikan bangkrut dan perusahaan yang memiliki nilai $\mathrm{Z}<8,27$ yaitu perusahaan yang dikategorikan tidak bangkrut. Ada dua perusahaan yang berada pada konisi bangkrut dengan nilai $\mathrm{Z}>8,27$ yaitu PT Asia Pacific Fibers Tbk, dan PT Argo Pantes Tbk. Nilai Z Score PT Asia Pacific Fibers Tbk sebesar 9,17, dan nilai Z Score PT Argo Pantes Tbk sebesar 10,683. Sedangkan 12 perusahaan lainnya berada pada kondisi tidak bangkrut yang memiliki $\mathrm{Z}<8,27$.

Dari 2 perusahaan yang awalnya diprediksi bangkrut dan 12 perusahaan yang diprediksi tidak bangkrut. Setelah menggunakan model diskriminan dengan didasarkan pada nilai cut off score yang telah ditentukan, terdapat 2 perusahaan bangkrut dan 12 perusahaan tidak bangkrut. Jadi dengan menggunakan model diskriminan pengklasifikasian yang benar adalah sebanyak 12 perusahaan dengan tingkat akurasi $100 \%$, dan pengklasifikasian yang salah tidak ada.

\section{PEMBAHASAN}

Model diskriminan untuk mengetahui kebangkrutan pada industri tekstil adalah:

$\mathrm{Z}=-2,174+-0,001 \mathrm{X} 2+0,002 \mathrm{X} 3+-0,024$ $\mathrm{X} 9+0,007 \mathrm{X} 11$

Critical cutting score untuk model p.ISSN: 2407-800X e.ISSN: 2541-4356 
diskriminan adalah:

Z> 8,27 ; perusahaan yang dikategorikan bangkrut

$\mathrm{Z}<8,27$; perusahaan yang dikategorikan tidak bangkrut

Rasio yang dapat menilai prediksi kebangkrutan perusahaan adalah Current Asset/Current Laibility, rasio Working Capital/Total Asset, Net Income/Total Asset dan Rasio Liability/Total Asset menunjukkan proporsi total aset untuk membiayai utang perusahaan. Rasio yang positif menunjukkan bahwa nilai aset lebih besar dari kewajiban perusahaan. Rasio yang negatif menunjukkan nilai aset lebih kecil dari kewajiban perusahaan. Ini berarti bahwa perusahaan mempunyai hutang yang lebih besar dibandingkan dengan aset yang dimiliki perusahaan.

Perusahaan yang bangkrut dengan menggunakan model diskriminan ada dua perusahan yaitu PT Argo Pantes Tbk dan PT Asia Pacific Fibers Tbk. PT Argo Pantes Tbk dengan nilai $\mathrm{Z}$ Score 9,170 dan perusahaan PT Asia Pacific Fibers Tbk dengan niai $Z$ Score 10,683. Perusahaan-perusahaan tersebut memiliki nilai $\mathrm{Z}$ Score lebih besar dari nilai cut off score yaitu sebesar 8,27 sehingga perusahaan tersebut digolongkan pada kelompok perusahaan yang mengalami kebangkrutan.

\section{SIMPULAN}

Model prediksi kebangkrutan pada industri tekstil adalah: $\mathrm{Z}=-2,174+-0,001 \mathrm{X} 2$ $+0,002 \mathrm{X} 3+-0,024 \mathrm{X} 9+0,007 \mathrm{X} 11$. Persentase tingkat akurasi model diskriminan adalah sebesar $100 \%$. Dengan menggunakan model diskriminan diatas dilakukan pengujian terhadap rasio-rasio keuangan.

Rasio keuangan dapat digunakan untuk membedakan antara perusahan yang distress dan perusahaan yang tidak distress. Dari hasil pengujian menggunakan analisis diskriminan menunjukkan bahwa rasio yang dapat membedakan antara perusahaan yang distress dan perusahaan yang tidak distress pada industri tekstil adalah empat rasio keuangan Current Asset/Current Liability, rasio Working Capital/Total Asset, Net
Income/Total Asset dan Rasio Liability/Total Asset.

\section{DAFTAR RUJUKAN}

Agnes Sawir. 2003. Analisis Kinerja keuangan dan Perencanaan Keuangan Perusahaan. PT Gramedia Pustaka Utama, Jakarta.

Altman, Edward, I. 1968. Financcial Ratio, Discriminant Analysis and The Prediction of Corporate Bankruptcy. The Journal of Finance (September): 589-609

Altman, Edward, I. 2000. Predicting Financial Distress of Companies: Revisiting The Z Score adn Zeta ${ }^{\circledR}$ Models.

Avianti, Ilya. 2002. Bankruptcy Prediction Models for Companies Listed at the Jakarta Stock Exchange Using Financial Indicators. Economics Journal FE-Unpad

Brigham F. Eugene. 2004. Intermediate Financial Management. Eight Edition. Thomson South Western, USA

Gitman, Lawrence J. 2006. Principle of Maganerial Finance. Eight Edition. Pearson Eaducation, Inc, BostonUnites States of America

Hadad, Muliaman D., Santoso, Wimboh., Ruliana, ita. 2003. Indikator Kepailitan di Indonesia: An Additional Early Warning Tools Pada Stabilitas Keuangan

Mamduh M. Hnafi, dan Abdul Hakim. 2005. Analisis Lporan Keuangan. Edisi Kedua. UPP AMP YKPN. Yogyakarta. 
Palepu, Khrisna G. At.all.2004. Busines Analysis \& Valuation, Third Edition. Thomson Learning, unites States of America

Sarwono, jonathan. 2006. Panduan Cepat dan Mudah SPSS 14. CV Andi Offset. Yogyakarta

Weston, and Brigham. 1993. Essential of Managrial Finannce, Tenth Edition. Harcourt Brace College Publisher, Unites States of America

White, Gerald, I., Sondhi, Shwinpaul, C., Fried, Dov. 2003. The Analysis and Use of Financial Statement. Third Eddition. John Willey \& Sons, Inc, Unites States of America 